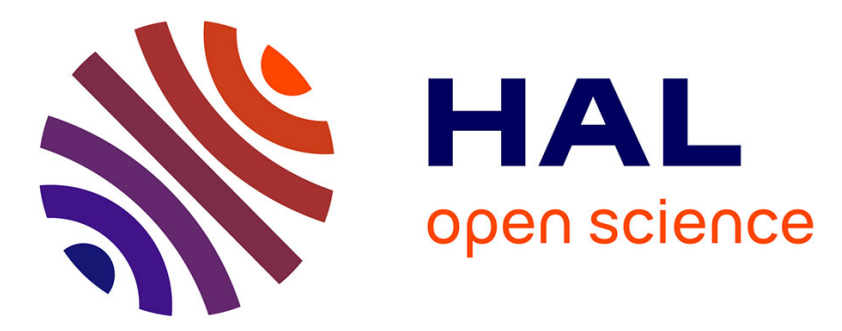

\title{
Direct analysis of microaggregates shrinkage for drying: Application to microaggregates from a Brasilian clayey Ferralsol.
}

\author{
Nathalie Volland-Tuduri, Michel Brossard, Ary Bruand, Henri Garreau
}

\section{- To cite this version:}

Nathalie Volland-Tuduri, Michel Brossard, Ary Bruand, Henri Garreau. Direct analysis of microaggregates shrinkage for drying: Application to microaggregates from a Brasilian clayey Ferralsol.. Comptes Rendus Géoscience, 2004, 336, pp.ํำ11, 1017-1024. 10.1016/j.crte.2004.03.003 . hal-00022694

\section{HAL Id: hal-00022694 \\ https://hal-insu.archives-ouvertes.fr/hal-00022694}

Submitted on 12 Apr 2006

HAL is a multi-disciplinary open access archive for the deposit and dissemination of scientific research documents, whether they are published or not. The documents may come from teaching and research institutions in France or abroad, or from public or private research centers.
L'archive ouverte pluridisciplinaire HAL, est destinée au dépôt et à la diffusion de documents scientifiques de niveau recherche, publiés ou non, émanant des établissements d'enseignement et de recherche français ou étrangers, des laboratoires publics ou privés. 


\title{
Direct analysis of microaggregates shrinkage for drying: Application to microaggregates from a Brasilian clayey Ferralsol
}

\author{
Nathalie Volland-Tuduri ${ }^{\mathrm{a} *}$ Michel Brossard $^{\mathrm{b}}$, Ary Bruand ${ }^{\mathrm{a}}$ et Henri Garreau ${ }^{\mathrm{c}}$

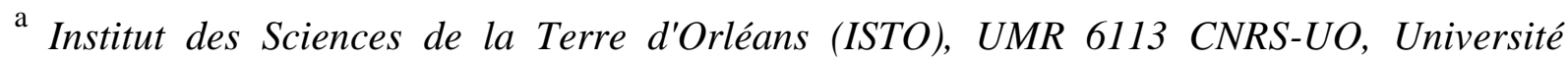 \\ d'Orléans, Géosciences, BP 6759, 45067 Orléans Cedex 2, France. \\ ${ }^{\mathrm{b}}$ IRD/Embrapa Cerrados, CP 7091, 71619-970 Brasilia-DF, Brésil. \\ ${ }^{\mathrm{c}}$ CRBA UMR 5473, Faculté de Pharmacie, BP 14491, 34093 Montpellier Cedex 05, France.
}

*Correspondance et tiré à part.

Adressese-mail : Nathalie.Volland@univ-orleans.fr

Brossard@ird.mpl.fr

Ary.Bruand@univ-orleans.fr

garreau@univ-montp1.fr

\begin{abstract}
Subrounded microaggregates 100 to $500 \mu \mathrm{m}$ in diameter were collected in a Ferralsol located in the state of Goiàs. Observation of these microaggregates in dry condition in scanning electron microscopy showed morphological characteristics that are representative of microaggregates described earlier in many Ferralsols. The shrinkage for drying of initially water saturated microaggregates was studied using a environmental scanning electron microscope. Results showed very small shrinkage for the microaggregates studied as usually considered. However the shrinkage varies since the volume of dried microaggregates was found to be 93 to $99 \%$ of their volume when they are saturated.
\end{abstract}

Cerrados / environmental scanning electron microscope / microped / structure

Résumé - Analyse directe du retrait de microagrégats durant la dessiccation : Application à des microagrégats d'un Ferralsol argileux brésilien. Des microagrégats de forme subarrondie et de 100 à $500 \mu \mathrm{m}$ de diamètre ont été prélevés dans un Ferralsol localisé dans l'état du Goiàs. L'observation à l'état sec de ces microagrégats en microscopie 
électronique à balayage a révélé des caractéristiques morphologiques qui sont représentatives des microagrégats décrits dans de nombreux autres Ferralsols. L'analyse du retrait lors de la dessiccation de microagrégats initialement saturés en eau a été effectuée en utilisant un microscope électronique à balayage environnemental. Les résultats montrent que ces microagrégats sont des structures faiblement déformables comme elles sont fréquemment considérées. Cependant, les propriétés de retrait varient puisque le volume des microagrégats après dessiccation est de 93 à $99 \%$ de celui des microagrégats saturés.

\section{Cerrados / microscope électronique à balayage environnemental / microped / structure}

\section{Version abrégée}

\section{Introduction}

La dynamique de la structure et de la porosité est étroitement liée dans un sol aux propriétés de retrait-gonflement des agrégats qui le constituent. Pour des agrégats de taille supérieure à quelques millimètres, de nombreuses méthodes existent pour étudier ces propriétés $[14,5]$. En revanche, lorsqu'ils sont de plus petite taille, on procède alors à des mesures indirectes [4] .

C'est le cas des Ferralsols [11] qui sont des sols microagrégés (microagrégats de quelques dizaines à quelques centaines de micromètres de diamètre) [10] et pour lesquels les propriétés de retrait-gonflement à l'échelle des microagrégats ont été jusqu'alors déduites de mesures réalisées sur des volumes de plusieurs centimètres cube, voire de plusieurs dizaines de centimètres cube $[17,8,5]$. Les microagrégats de Ferralsols correspondent aux «pseudosables », «micropeds » et «granules » qui ont été décrits respectivement par Kubiena [12], Brewer [6] et Trapnell et Webster [19]. Bien qu'ils soient généralement considérés comme étant des édifices très stables et rigides [3,13], il a été montré récemment, de façon indirecte, que ces microagrégats se déformeraient lors de la dessiccation [1]. Notre objectif est dans cette Note de quantifier, par des mesures directes, la variation de volume des microagrégats lors de leur dessiccation.

\section{Matériel et méthodes}


Les microagrégats étudiés ont été prélevés humides à 150-160 cm de profondeur dans un Ferralsol argileux localisé dans 1'état du Goiàs [2]. Ils ont été conservés à $5^{\circ} \mathrm{C}$ dans des récipients hermétiques.

Des microagrégats préalablement séchés à $40^{\circ} \mathrm{C}$ ont été observés en microscopie électronique à balayage à l'aide d'un microscope à émission de champ qui permet des observations de grande qualité à faible tension d'accélération sans que les échantillons aient été métallisés. D’autres microagrégats ont été inclus dans une résine de telle façon à confectionner une lame mince qui puisse être observée en mode électrons rétrodiffusés [7].

Des microagrégats encore humides ont aussi été observés en microscopie électronique à balayage à l'aide d'un microscope environnemental $[9,15,18]$. Les microagrégats ont été mis à l'équilibre avec un potentiel de $-10 \mathrm{hPa}$, et une température de $2^{\circ} \mathrm{C}$. Ils ont été introduits dans le microscope après avoir ajouté une goutte d'eau de façon à s'assurer qu'ils demeurent saturés dans la chambre du microscope lorsque la pression passe de la pression atmosphérique à 10 Torr. La déformation de sept microagrégats lors de la dessiccation a été suivie étape par étape jusqu'à l'état déshydraté (figure 1). Une dizaine de diamètres ont été mesurés pour chaque microagrégat alors qu'ils pouvaient encore être considérés comme étant saturés en raison de la présence de ménisques d'eau puis à l'état déshydraté après qu'ils aient été mis à l'équilibre avec une pression de 3 Torr et une température de $16^{\circ} \mathrm{C}$.

\section{Résultats et discussion}

Les images en mode électrons rétrodiffusés montrent un assemblage lâche de microagrégats de forme subarrondie et de 100 à $500 \mu \mathrm{m}$ de diamètre (figure 2a). Des grains de quartz de 10 à $70 \mu \mathrm{m}$ ainsi que des fissures de quelques micromètres de largeur sont présents au sein des microagrégats (figure $2 b$ ). Ces derniers présentent des caractéristiques morphologiques qui sont identiques à celles décrites par Balbino et al. [1, 2] dans des Ferralsols étudiés sur le même site et pour d'autres Ferralsols [12, 6, 19]. Les observations effectuées à fort grossissement à l'aide du microscope électronique à émission de champ montrent que les microagrégats sont composés d'un assemblage de particules de forme pseudo-hexagonale et de 0,05 à $0,3 \mu \mathrm{m}$ de diamètre (figure $2 c$, $d$, e et $f$ ). Ces particules sont très vraisemblablement des particules de kaolinite qui constituent la majeure partie de la phase argileuse des Ferralsols [11]. 
L'observation de microagrégat avec le microscope électronique à balayage environnemental à 10 Torr et $2^{\circ} \mathrm{C}$, montre des agrégats partiellement immergés dans l'eau (figure $3 a$ ). Une diminution de la pression à 7,2 Torr, la température demeurant à $2{ }^{\circ} \mathrm{C}$, provoque un approfondissement des ménisques ainsi qu'une meilleure définition des contours des microagrégats (figure $3 b$ ). A 5,1 Torr et $2^{\circ} \mathrm{C}$, on se situe juste en dessous de la courbe délimitant les domaines de l'eau liquide et vapeur (figure 1). On assiste à une dessiccation progressive des microagrégats. Un film d'eau est encore visible de façon transitoire à la surface des microagrégats. On observe aussi quelques ménisques d'eau de petite taille entre les microagrégats (figure $3 c$ et $3 d$ ) qui diminuent progressivement (figure 3 e). Enfin, après élimination de la totalité de l'eau liquide, la pression ayant été amenée à 3 Torr et la température à $16^{\circ} \mathrm{C}$, ce sont des microagrégats à l'état sec qui sont observés (figure $3 f$ ).

Nous avons mesuré le diamètre moyen des microagrégats quand ils étaient encore à l'état saturé comme observé figure $3 d$. Les mêmes diamètres ont été mesurés lorsque les microagrégats étaient à l'état sec comme observé figure $3 f$, afin de calculer la variation moyenne du retrait. Les résultats montrent que le retrait linéaire des agrégats saturés varie de 0,3 à 2,4\% (tableau 2). Le retrait volumique a été calculé en utilisant la relation suivante :

$$
\frac{V_{\mathrm{d}}}{V_{\mathrm{s}}}=\left[1-\left(\frac{D_{\mathrm{s}}-D_{\mathrm{d}}}{D_{\mathrm{s}}}\right)\right]^{3}
$$

avec $V_{\mathrm{s}}$ et $V_{\mathrm{d}}$, le volume spécifique en $\mathrm{cm}^{3} \mathrm{~g}^{-1}$ des microagrégats respectivement déshydratés et saturés, $D_{\mathrm{s}}$ et $D_{\mathrm{d}}$, le diamètre moyen des microagrégats respectivement déshydratés et saturés en unité de longueur. Les résultats montrent que les volume spécifique des microagrégats déshydratés est 93 à $99 \%$ de celui des microagrégats saturés, la valeur moyenne étant de $97 \%$.

\section{Conclusion}

Les résultats présentés dans cette Note montrent que les microagrégats sélectionnés sont dans l'ensemble des édifices qui se déforment très peu lors de la dessiccation. Ces résultats sont cohérents avec ceux obtenus par Pedro et al. [17] et Chauvel et Pédro [8] à partir de mesures indirectes. Le retrait moyen enregistré est en effet très faible mais nous observons aussi qu'il varie selon les agrégats étudiés. Il est cependant cohérent avec le retrait enregistré par Balbino et al. [1] pour des microagrégats de Ferralsols de très faible teneur en matière organique. La variabilité du retrait enregistrée entre les différents microagrégats étudiés 
pourrait être liée à des différences de composition ou de mode d'assemblage des constituants. C'est pourquoi, le retrait de microagrégats, possédant des teneurs en matière organique et des minéralogies variables, devra être étudié de façon à déterminer comment il varie en fonction des variations de composition. Enfin, la microscopie électronique à balayage environnementale qui devient d'un accès plus facile devrait permettre de nombreuses études de la déformation des sols lors de la dessiccation et de l'humectation, à des échelles qui n'étaient jusqu'alors pas directement accessibles.

\section{Introduction}

Dynamics of the soil structure and porosity is closely related to the shrinkage properties of the aggregates making up the soil. Indeed, the shrinkage properties are responsible for the opening of the inter-aggregates voids when the aggregates dry and the cracking of the soil, thus enabling the regeneration of the structure when the soil is massive. If shrinkage can be measured on aggregates a few millimeters to several decimeters in size [14, 4, 5], its measurement on aggregates several dozens to several hundreds micrometers in size cannot be performed with the same methods because of their very small size.

Among soils that are microaggregated, there are Ferralsols [11] that correlate to Latosols of the Brazilian soil classification [10] and show little or no distinct horizonation. Their macrostructure is weak to moderate and they have typically a strong microstructure $[16,20]$. Microaggregates are near spherical, ranging from 80 to $200 \mu \mathrm{m}$ in size usually. They correspond to the 'pseudosand', 'micropeds', 'granules' which were described earlier by Kubiena [12], Brewer [6] and Trapnell \& Webster [19], respectively.

Since Ferralsols have no or little macrostructure, their porosity and more generally their mechanical and hydraulic properties are closely related to the arrangement of the microaggregates and the clay particles within the microaggregates. In many studies, the microaggregates are considered as very stable and rigid fabric [3, 13]. However, the shrinkage and swelling properties of the microaggregates and their consequences on the pore-size distribution are still under discussion because there is a lack of direct measurement of these properties. Indeed, using macroscopic measurements on samples several cubic centimeters to several dozens of cubic centimeters in volume, several authors inferred a lack of shrinkage for the microaggregates [17, 8]. On the other hand, Balbino et al. [1] compared the water retention of microaggregates with their pore-size distribution when they have dried and 
showed that there was a deformation of the pores and probably a shrinkage of the microaggregates for drying. Our objective in this study is to show that measurement of microaggregates size for drying using a environmental scanning electron microscope enables direct quantification of microaggregates shrinkage .

\section{Material and Methods}

The microaggregates studied were collected in a Ferralsol located $30 \mathrm{~km}$ north of Planaltina de Goiàs in the state of Goiàs $\left(15^{\circ} 14^{\prime} \mathrm{S}, 47^{\circ} 42^{\prime} \mathrm{W}\right)$ [2] under native vegetation (Cerradão) at 150-160 cm depth (table 1). The microaggregates were stored at $5^{\circ} \mathrm{C}$ to reduce biological activity and in sealed plastic containers to avoid water loss.

Dried microaggregates were examined first in scanning electron microscopy (SEM). The microaggregates were dried at $40^{\circ} \mathrm{C}$ and examined by SEM using a scanning electron microscope equipped with a field emission gun (FESEM Hitachi 4200). This permitted high resolution observation at low voltage without any coating of the surface sample. Working at low voltage $(2 \mathrm{kV})$ also minimize any possible damage caused by electron beam. Other dried microaggregates were impregnated with a polyester resin to produce a thin section [7]. The latter was examined by SEM (Cambridge 90B) using the emission of backscattered electrons.

Then, wet microaggregates were examined with an environmental SEM (XL 30 ESEM, Philips, Netherlands) that enables visualization of uncoated and moist samples in gaseous atmosphere in a vacuum range of 0,1-10 Torr [9, 15, 18]. The presence of a low-pressure water vapour atmosphere in the ESEM chamber and the utilization of cooling stage permit the observation of the sample during hydration or dehydration. Microaggregates never dried were wetted at $-10 \mathrm{hPa}$ in a pressure cell as indicated by Balbino et al. [1]. They were installed onto a 13-mm diameter aluminium stub. A small drop of water was added to ensure that microaggregates remain saturated when the pressure is set to 10 Torr in the ESEM chamber. Progressive dehydration of the microaggregates was obtained by reducing progressively the pressure to 3 Torr (figure 1). Then, temperature was raised to $16^{\circ} \mathrm{C}$ to ensure complete dehydration of the microaggregates. Observations were performed along the dehydration process on seven microaggregates 100 to $300 \mu \mathrm{m}$ in diameter. About ten diameters were measured for every microaggregate when it was still saturated as indicated by the presence of meniscus of water and when it was dehydrated because in equilibrium with $16^{\circ} \mathrm{C}$ and 3 Torr. 


\section{Results and discussion}

Backscattered electron scanning images (BESI) showed a loose arrangement of subrounded microaggregates 100 to $500 \mu \mathrm{m}$ in diameter (figure $2 a$ ). Quartz grains 10 to $70 \mu \mathrm{m}$ and cracks a few micrometers in thickness were visible in the clay phase of the microaggregates (figure $2 b$ ). These microaggregates are similar to those described by Balbino et al. [1, 2] in Ferralsols located at the same site and in other Ferralsols [6, 12, 19]. Secondary electron scanning images with the FESEM showed that the uncoated microaggregates exhibit a rough surface (figures $2 c \& 2 d$ ) where pseudo-hexagonal elementary particles 0.05 to 0.3 $\mu \mathrm{m}$ in size were visible (figures $2 e \& 2 f$ ). These particles would correspond to particles of kaolinite that compose the bulk of the clay phase of Ferralsols [11].

Examination of the microaggregates with the ESEM at 10 Torr and $2{ }^{\circ} \mathrm{C}$, showed the top of microaggregates that are partially submerged in water (figure $3 a$ ). A decrease in the pressure to 7.2 Torr, the temperature remaining at $2^{\circ} \mathrm{C}$, led to a deepening of the menisci and the contours were more visible (figure $3 b$ ). At 5.1 Torr and $2{ }^{\circ} \mathrm{C}$, we were right under the saturation line and water evaporated (figure 1). Water was still visible at the surface of the microaggregates and in the form of small menisci between the microaggregates (figure $3 c \&$ $3 d$ ). Then without any variation of the pressure, the menisci disappeared (figure 3e). Finally, examination of the microaggregates at 3.0 Torr and $2^{\circ} \mathrm{C}$, after complete removal of water at 3.0 Torr and $16^{\circ} \mathrm{C}$, showed dried microaggregates (figure $3 f$ ).

We measured diameters of the microaggregates when they were in a hydration state corresponding approximately to Figure $3 \mathrm{~d}$. The same diameters were also measured on the microaggregates when they were dry (figure 3f). Results showed that linear shrinkage expressed as percentage of the diameter of the saturated microaggregates ranged from 0.3 to $2.4 \%$ (table 2). The volumetric shrinkage was computed using the following relationship:

$$
\frac{V_{\mathrm{d}}}{V_{\mathrm{s}}}=\left[1-\left(\frac{D_{\mathrm{s}}-D_{\mathrm{d}}}{D_{\mathrm{s}}}\right)\right]^{3}
$$

with $V_{\mathrm{s}}$ and $V_{\mathrm{d}}$, the specific volume in $\mathrm{cm}^{3} \mathrm{~g}^{-1}$ of the dried and saturated microaggregates respectively, $D_{\mathrm{s}}$ and $D_{\mathrm{d}}$, the mean diameter of the dried and saturated microaggregates, respectively in length unit. Results showed that the volume of dried microaggregates was 93 to $99 \%$ of their volume when they are saturated with a mean value of $97 \%$.

\section{Conclusion}


Our results showed that the microaggregates selected are rather rigid fabrics. They are consistent with those published earlier by Pedro et al. [17] and Chauvel and Pédro [8] using macroscopic shrinkage measurements that were in favour of a lack of shrinkage for microaggregates. However, our results showed also that though the shrinkage recorded is very small, it varies between the microaggregates studied. That shrinkage is consistent with the shrinkage of the clayey phase recorded by Balbino et al. [1] for microaggregates with a very small organic matter content. The variability of microaggregates shrinkage could be due to specific composition and/or gathering of constituents. Thus, shrinkage of microaggregates with greater organic matter content and other mineralogy needs to be investigated to determine how shrinkage varies with soil composition. Finally, environmental scanning electron microscopy that becomes more widely applicable should lead to many studies of soil deformation when for drying and wetting.

\section{References}

[1] Balbino, L.C., Bruand, A., Brossard, M., Guimarães, M.F., 2001. Comportement de la phase argileuse lors de la dessiccation dans des Ferralsols microagrégés du Brésil : rôle de la microstructure et de la matière organique. Comptes Rendus de l'Académie des Sciences, 332: 673-680.

[2] Balbino, L.C., Bruand, A., Brossard, M., Grimaldi, M., Hajnos, M., Guimarães, M.F., 2002. Changes in porosity and microaggregation in clayey Ferralsols of the Brazilian Cerrado on clearing for pasture. European Journal of Soil Science, 53: 219-230.

[3] Bartoli, F., Burtin, G. and Guerif, J., 1992. Influence of organic matter on aggregation in Oxisols rich in gibbsite or in goethite. II. Clay dispersion, aggregate strength and waterstability. Geoderma, 54: 259-274.

[4] Braudeau, E., and A. Bruand. 1993. Détermination de la courbe de retrait de la phase argileuse à partir de la courbe de retrait établie sur échantillons de sol non remanié. Application à une séquence de sols de Côte-d'Ivoire. Comptes Rendus de l'Académie des Sciences 316:685-692.

[5] Braudeau, E., Costantini, J.M., Bellier, G. and Colleuille, H., 1999. New Device and Method for Soil Shrinkage Curve Measurement and Characterization. Soil Science Society of America Journal, 63: 525-535. 
[6] Brewer, R. 1964. Fabric and Mineral Analysis of soils. John Wiley \& Sons, New York.

[7] Bruand, A., Cousin, I., Nicoullaud, B., Duval, O. \& Bégon, J.C. 1996. Backscattered electron scanning images of soil porosity for analyzing soil compactation around roots. Soil Science Society of America Journal, 60, 895-901.

[8] Chauvel, A. and Pédro, G., 1978. Sur l'importance de l'extrême dessiccation des sols (ultra-dessiccation) dans l'évolution pédologique des zones tropicales à saisons contrastées. Comptes Rendus de l'Académie des Sciences, t.286(Note série D): 1581-1584.

[9] McDonough, C.M., Rooney, L.W., 1999. Use of the environmental scanning electron microscope in the study of cereal-based foods. Ceral Foods World, 44, 342-348.

[10] EMBRAPA 1999. Centro Nacional de Pesquisa de solos (Rio de Janeiro, RJ). Sistema brasileiro de classificação de solos. Embrapa Produção de Informação, Embrapa Solos, Brasília, DF.

[11] ISSS Working Group R.B. 1998. World Reference Base for Soil Resources: Introduction. In: J.A. Deckers, F.O. Nachtergaele and O.C. Spaargaren (Editors), First Ed. International Society of Soil Science (ISSS). ISRIC-FAO-ISSS-Acco. Leuven.

[12] Kubiena, M.L. 1950. Zur micromorphologie der braunen and roten tropenboden. Transactions of the $4^{\text {th }}$ International Congress of Soil Science, Amsterdam, 1, 304-307.

[13] Lehmann, J., Cravo, M.d.S. and Zech, W., 2001. Organic matter stabilization in a xanthic ferralsol of the central Amazon as affected by single trees: chemical characterization of density, aggregate, and particle size fractions. Geoderma, 99: 147-168.

[14] Monnier G., Stengel P., Fiès J.-C., 1973. Une méthode de mesure de la densité apparente des petits agglomérats terreux. Application à l'analyse des systèmes de porosité du sol. Ann. Agron., 24(5): 533-545.

[15] Montes-Hernandez, G., Duplay, J., Martinez, L. and Mendoza, C., 2003. Swellingshrinkage kinetics of MX80 bentonite. Applied Clay Science, 22: 279-293.

[16] Neufeldt, H., Ayarza, M.A., Resk, D.V.S., Zech, W., 1999. Distribution of waterstable aggregates and aggregating agents in Cerrado Oxisols. Geoderma, 93: 85-99.

[17] Pédro, G., Chauvel, A. and Melfi, A.J., 1976. Recherches sur la constitution et la genèse des Terra Roxa Estructurada du Brésil. Annales agronomiques, 27(3): 265-294.

[18] Roman-Gutierrez, A.D., Guilbert, S. and Cuq, B., 2002. Description of Microstructural Changes in Wheat Flour and Flour Components during Hydratation by using Environmental Scanning Electron Microscopy. Lebensm.-Wiss. u.-Technol., 35: 730-740. 
[19] Trapnell, C.G., Webster, R. 1986. Microaggregates in red earths and related soils in East and Central Africa, their classification and occurrence. Journal of Soil Science, 37, 109123.

[20] Westerhof R., Buurman P., Van Griethuysen C., Ayarza M., Vilela L., Zech W., 1999. Aggregation studied by diffraction in relation to plowing and liming in the Cerrado region in Brazil. Geoderma, 90: 277-290. 


\section{Figures}

Figure 1: Path followed by the microaggregates during the dehydration in the chamber of the environmental scanning electron microscope. The letters correspond to the hydration states at which images were taken.

Trajet suivi par les microagrégats durant la déshydratation dans la chambre du microscope électronique à balayage environnemental. Les lettres correspondent à l'état d'hydratation auquel les images ont été prises.

Figure 2: Dried microaggregates in scanning electron microscopy: a and b, back-scattered electron scanning electron images at an acceleration voltage of $15 \mathrm{kV}$ (the black areas are voids occupied by resin, the light grey areas are quartz grains and the heterogeneous dark grey areas correspond to clay particles), c, d, e and f, secondary electron scanning images at an acceleration voltage of $2 \mathrm{kV}$ (c, d and e) and $15 \mathrm{kV}$ (f).

Microagrégats secs observés au microscope électronique à balayage : a et b, images en mode électrons rétrodiffusés à une tension d'accélération de $15 \mathrm{kV}$ (les zones noires représentent les vides occupés par la résine, les plages gris clair correspondent aux grains de quartz et les domaines gris foncés hétérogènes correspondent à la phase argileuse), $c$, $d$, e et $f$, images en mode électrons secondaires à une tension d'accélération de $2 \mathrm{kV}(\mathrm{c}$,d et e) et $15 \mathrm{kV}(f)$.

Figure 3: Drying of microaggregates in environmental scanning electron microscopy: a and b, partially submerged microaggregates at 10 and 7.2 Torr, respectively, and $2{ }^{\circ} \mathrm{C} ; \mathrm{c}, \mathrm{d}$ and e, drying microaggregates at 5.1 Torr and $2^{\circ} \mathrm{C}$; f, dried microaggregates at 3 Torr and $2^{\circ} \mathrm{C}(\mathrm{M}$ : meniscus, W: film of water).

Déshydratation de microagrégats observée à l'aide d'un microscope électronique à balayage environnemental: $a$ et $b$, microagrégats partiellement submergés à 10 et 7,2 Torr respectivement et $2{ }^{\circ} \mathrm{C}$; $c$, d et e, déshydratation des microagrégats à 5,1 Torr et $2{ }^{\circ} \mathrm{C} ; f$, microagrégats secs à 3 Torr et $2{ }^{\circ} \mathrm{C}(M$ : ménisque, $W$ : film d'eau). 


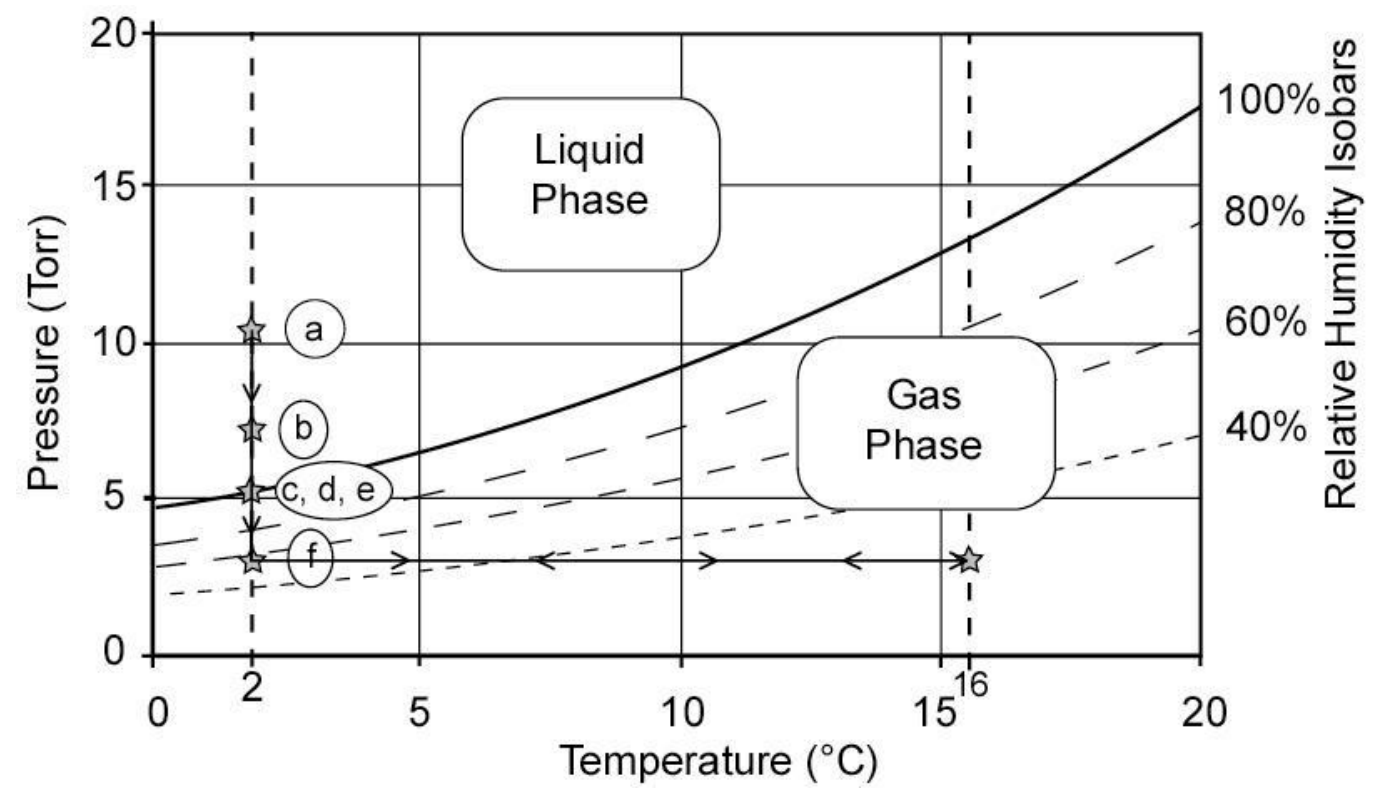



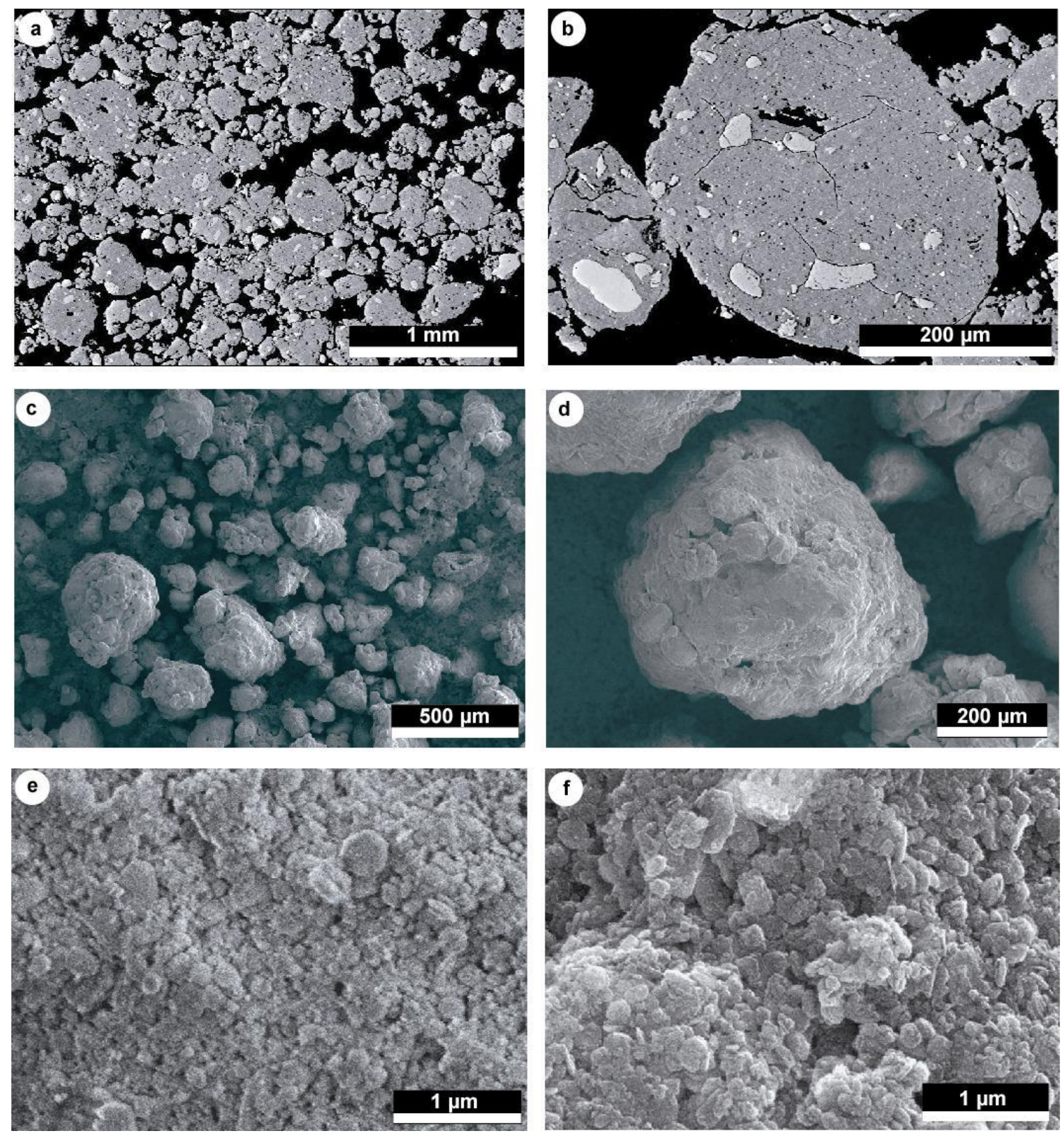

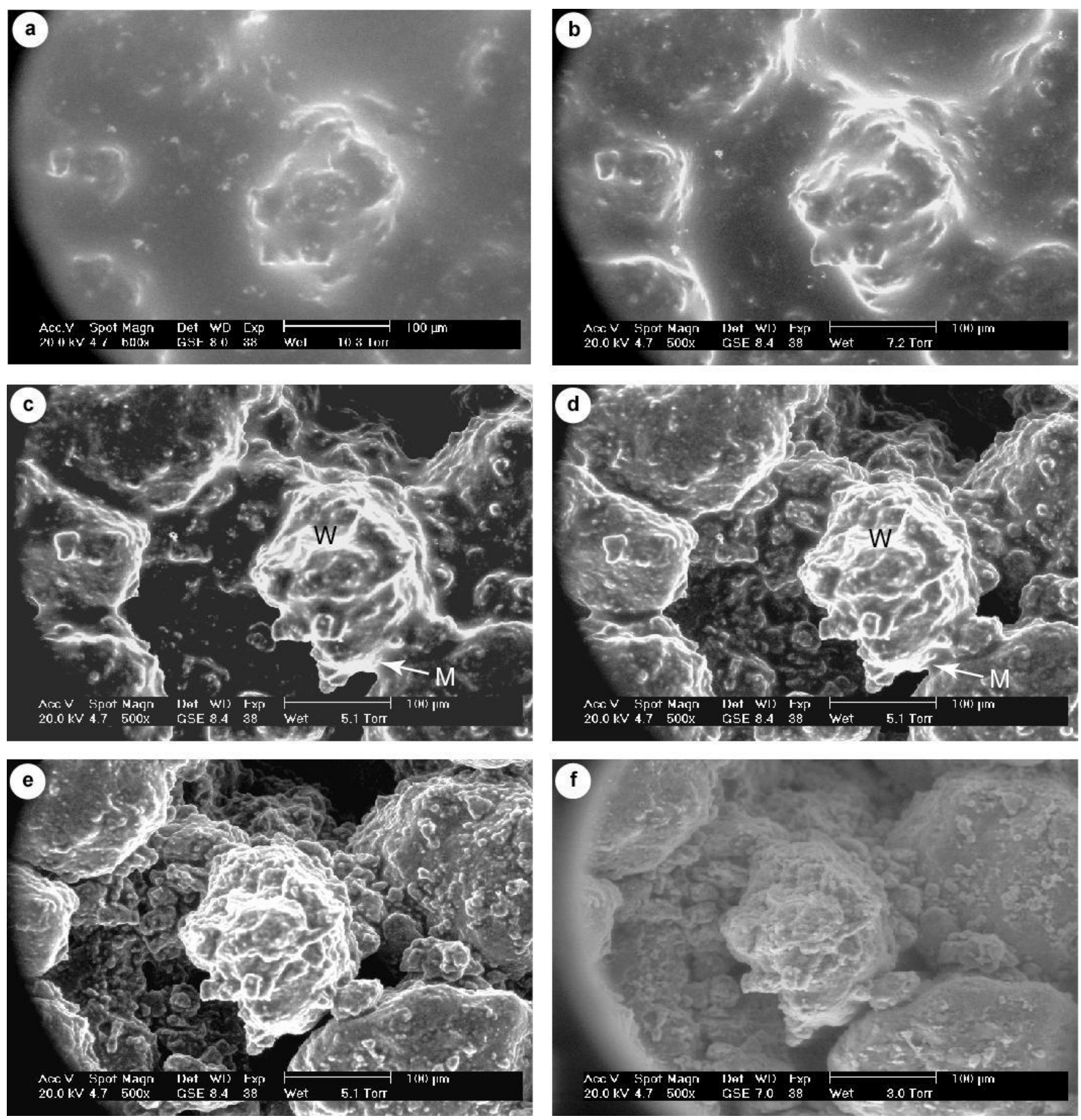
Table 1. Physical and chemical characteristics of soils studied: bulk density $\left(D_{\mathrm{b}}\right)$ in $\mathrm{g} \mathrm{cm}^{-3}$; particle size distribution and total organic carbon (TOC) in $\mathrm{g} \mathrm{kg}^{-1} ; \mathrm{pH}$ in water $\left(\mathrm{pH}_{\mathrm{w}}\right)$, cation exchange capacity (CEC) and exchangeable cations $\left(\mathrm{Al}^{3+}, \mathrm{K}^{+}, \mathrm{Ca}^{2+}, \mathrm{Mg}^{2+}\right)$ in $\mathrm{cmol}_{\mathrm{c}} \mathrm{kg}^{-1}$.

Tableau 1. Caractéristiques physiques et chimiques des sols étudiés : masse volumique apparente $\left(D_{b}\right)$ en $\mathrm{g} \mathrm{cm}^{-3}$; composition granulométrique et teneur en carbone organique total (TOC) en $\mathrm{g} \mathrm{kg}^{-1} ; \mathrm{pH}$ dans l'eau $\left(\mathrm{pH}_{\mathrm{w}}\right)$; capacité d'échange cationique (CEC) et cations échangeables $\left(\mathrm{Al}^{3+}, \mathrm{K}^{+}, \mathrm{Ca}^{2+}, \mathrm{Mg}^{2+}\right)$ en $\mathrm{cmol}_{\mathrm{c}} \mathrm{kg}^{-1}$.

\begin{tabular}{|c|c|c|c|c|c|c|c|c|c|c|c|}
\hline \multirow{2}{*}{ Depth $(\mathrm{cm})$} & \multirow{2}{*}{$\mathbf{D}_{\mathrm{b}}$} & \multicolumn{3}{|c|}{ Granulometry } & \multirow{2}{*}{ TOC } & \multirow{2}{*}{$\mathbf{p} \mathbf{H}_{\mathbf{w}}$} & \multicolumn{5}{|c|}{ Cation exchange capacity } \\
\hline & & $<2 \mu \mathrm{m}$ & $2-50 \mu \mathrm{m}$ & $50-2000 \mu \mathrm{m}$ & & & CEC & $\mathrm{Al}^{3+}$ & $\mathbf{K}^{+}$ & $\mathrm{Ca}^{2+}$ & $\mathrm{Mg}^{2+}$ \\
\hline $150-160$ & 0.96 & 740 & 175 & 85 & 2.1 & 5.1 & 2.80 & 0.14 & 0.02 & 0.01 & 0.02 \\
\hline
\end{tabular}

Table 2. Shrinkage estimation at the time of desiccation of seven microaggregates and ESEM parameters.

Tableau 2. Estimation du retrait lors de la dessiccation de sept microagrégats et paramètres du microscope électronique à balayage environnemental.

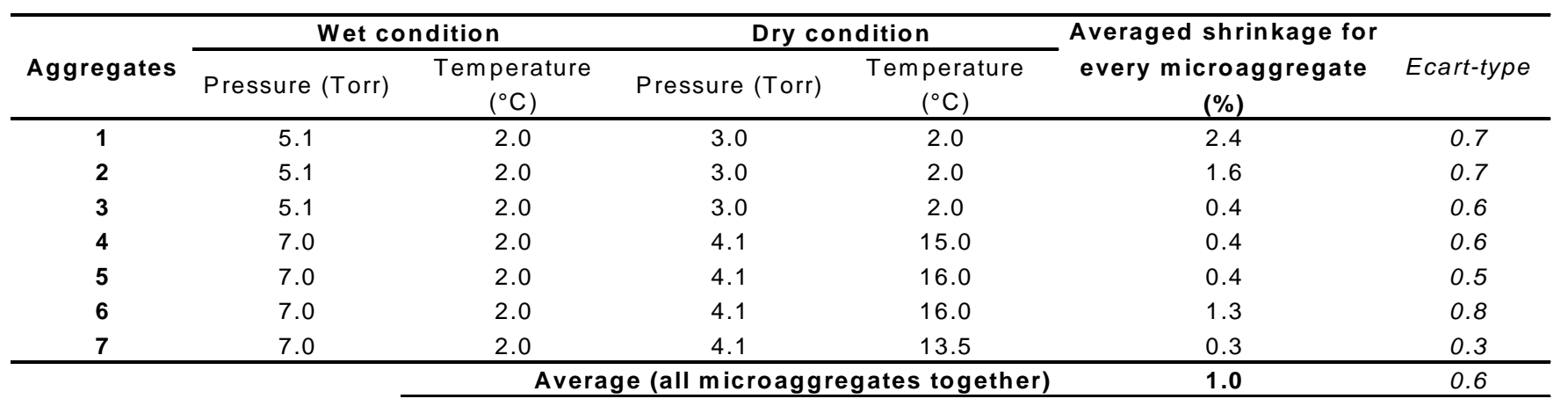

